\title{
Low 25-hydroxyvitamin D level increases carotid intima-media thickness in elderly women
}

\author{
Yudhisman Imran*, Andini Aswar*, Irmiya Rachmiyani**, and Donna Adriani***
}

\begin{abstract}
*Department of Neurology, Faculty of Medicine,

Trisakti University, Jakarta

**Department of Gynecology and Obstetrics, Faculty of Medicine,

Trisakti University, Jakarta

*** Department of Physiology,

Faculty of Medicine,

Trisakti University, Jakarta

\section{BACKGROUND}

Cerebrovascular disease occurs due to atherosclerosis of the carotid artery triggered by endothelial dysfunction, which can be assessed by measuring the carotid intima-media thickness (CIMT). There are several risk factors contributing to endothelial dysfunction, such as 25-hydroxyvitamin D [25(OH)D] deficiency. A number of research studies have shown variable results on the relationship between $25(\mathrm{OH}) \mathrm{D}$ deficiency and endothelial dysfunction. The objective of the present study was to determine the relationship between $25(\mathrm{OH}) \mathrm{D}$ and CIMT in elderly women.
\end{abstract}

\section{Correspondence:}

dr Yudhisman Imran, Sp.S.

Department of Neurology,

Faculty of Medicine,

Trisakti University

Jln Kyai Tapa No 260,

Grogol -Jakarta Barat 11440

Email: yudhisman.imran@trisakti.ac.id

Date of first submission, January 21, 2019

Date of final revised submission, July 17,2019

Date of acceptance, July 19, 2019

This open access article is distributed under a Creative Commons AttributionNon Commercial-Share Alike 4.0

International License

Cite this article as: Imran Y, Aswar A, Rachmiyani I, et al. Low 25hydroxyvitamin D level increases carotid intima-media thickness in elderly women. Univ Med 2019;38:114-20. doi: 10.18051/UnivMed.2019.v38.114120

\section{METHODS}

A cross-sectional study was conducted involving 45 elderly women aged $\geq 60$ years. The inclusion criteria were: able to communicate well and able to walk actively without any help. The exclusion criteria were: not having diabetes mellitus, stroke, heart disease, kidney disease, not consuming vitamin D or medicines containing corticosteroids, and not using hormone replacement therapy. Laboratory examination was conducted for fasting blood sugar, lipid profile, and 25(OH)D. CIMT was measured using carotid Doppler ultrasonography at the left carotid artery. Simple linear regression analysis was used to analyze the data.

\section{RESULTS}

Mean 25(OH)D level was $11.753 \pm 4.027 \mathrm{ng} / \mathrm{mL}$, and mean CIMT $0.61 \pm 0.10$ $\mathrm{mm}$. Simple regression analysis showed a significant relationship between 25(OH)D level and CIMT $(\beta=-0.001 ; 95 \%$ C.I. $=-0.020-0.003 ; p=0.009)$.

\section{CONCLUSION}

Our data suggest an inverse association between 25(OH)D level and CIMT in elderly women. This study supports the protective role of vitamin D against subclinical atherosclerosis in elderly women.

Keywords: Endothelial dysfunction, 25(OH) vitamin D, carotid intima-media thickness, elderly women 


\section{INTRODUCTION}

Atherosclerosis is a process that progresses slowly in stages, starting in childhood and advancing up to adult age at varying rates and is prone to cause complications. The initial structural change that can be detected in atherosclerosis is an increase in carotid intimamedia thickness (CIMT), ${ }^{(1)}$ which leads to the presence of atherosclerosis of the carotid arteries, an important factor in patients with ischemic stroke, ${ }^{(2)}$ and is a strong predictor for future vascular conditions of the patients. ${ }^{(3)}$

Atherosclerosis is associated with inflammation resulting from several factors, such as vitamin D deficiency. ${ }^{(4)}$ Vitamin D receptors are present in all cells of the body and influence the atherosclerotic process, i.e. maintaining endothelial function of the blood vessels, inhibiting the proliferation of smooth muscle cells and playing a role as natural immunomodulators. ${ }^{(5)}$ Vitamin $\mathrm{D}$ has a protective effect against endothelial dysfunction and the inflammatory process that precedes atherosclerosis. Vitamin D stimulates nitric oxide (NO) synthesis ${ }^{(6)}$ and decreases oxidative stress in the endothelium. ${ }^{(7)}$ The anti-atherogenic effect of 25-hydroxyvitamin D [25(OH)D] constitutes a specific influence on the immune system, by exerting a direct effect on CD4 cells and stimulating an increase in type 2 T-helper (Th2) lymphocytes, and is responsible for interleukin 10 (IL-10) synthesis by inhibiting the macrophage activation that is the key to the atherogenic process. In addition, it also inhibits the transcription of interferon- $\gamma($ IFN- $\gamma){ }^{(8)}$

In its protection against atherosclerosis, $25(\mathrm{OH}) \mathrm{D}$ also represses the expression of matrix metalloproteinases (MMPs), which are tissue enzymes that are secreted by activated macrophages in the inflammatory process and play a role in remodeling of the blood vessel wall and the myocardium. In addition, MMPs also damage the collagenous tissues in the atherosclerotic lesion and cause atherosclerotic rupture that subsequently results in thrombosis. ${ }^{(9)}$
Lesions in the carotid arteries may cause embolism in the brain. Half of all strokes is caused by atherosclerosis. Atherosclerosis in the carotid arteries can be seen with carotid duplex ultrasonography and the flow rate of the circulation can be seen with transcranial Doppler ultrasonography. ${ }^{(10)}$

Vitamin D deficiency influences the activity of macrophages and lymphocytes in atherosclerotic plaques and causes chronic inflammation of the arterial wall. ${ }^{(3)}$ In addition, there occurs endothelial dysfunction in the form of a decrease in total nitric oxide (NO) and an increase in reactive oxygen production. ${ }^{(11)}$ Vitamin D deficiency also inhibits the proliferation and differentiation of $\mathrm{CD} 4$ cells into Th1, Th17, and Th2. ${ }^{(5)}$

Deficiency of $25(\mathrm{OH}) \mathrm{D}$ is found in approximately $50 \%$ of the world population and in $25 \%$ to $57 \%$ of that of the United States. ${ }^{(5)}$ In Indonesia according to the study results of Oemar et al. ${ }^{(12)}$ the prevalence of $25(\mathrm{OH}) \mathrm{D}$ deficiency is $50 \%$ in women aged $45-55$ years. The study of Setiati et al. ${ }^{(13)}$ in Jakarta and Bekasi encountered $25(\mathrm{OH}) \mathrm{D}$ deficiency in $35.1 \%$ of women aged 60-75 years. Other investigators, namely Arifin et al. ${ }^{(14)}$ showed that $25(\mathrm{OH}) \mathrm{D}$ deficiency in postmenopausal women attending the obstetrics polyclinic of RSUPN Cipto Mangunkusumo Jakarta attained $81 \%$.

Research conducted by Carrelli et al. ${ }^{(3)}$ using a cross-sectional study involving 203 subjects aged 50 - 93 years indicates that low 25(OH)D concentrations are associated with increased CIMT. Essentially identical results were found in a cross-sectional study carried out by Reis et al., involving 654 community-dwelling older adults aged 55-96 years, ${ }^{(15)}$ where in subgroup analyses, low levels of $25(\mathrm{OH}) \mathrm{D}$ were inversely associated with CIMT among those with hypertension. Differing from the study results of Carelli et al. ${ }^{(3)}$ and Reis et al., ${ }^{(16)}$ a cohort study by Deleskog et al. ${ }^{(16)}$ on 3430 adult and elderly subjects found that low vitamin D was not independently associated with increased CIMT. Therefore the results of the various 
studies on the relationship between $25(\mathrm{OH}) \mathrm{D}$ and CIMT as marker of subclinical atherosclerosis and predictor of cardiovascular and cerebrovascular disease are still contradictory.

25-Hydroxyvitamin D deficiency is an emerging mayor public health problem and has important implications toward cardiovascular and cerebrovascular morbidity. Based on the still inconsistent study results, further studies are needed with the aim to determine the relationship between 25(OH)D concentration and CIMT in elderly women.

\section{METHODS}

\section{Study design}

This was an analytical cross-sectional study to determine the relationship between $25(\mathrm{OH}) \mathrm{D}$ and CIMT in elderly women in 5 villages (kelurahan) in Mampang Prapatan District, South Jakarta, consisting of the villages of Kuningan Barat, Mampang Prapatan, Tegal Parang, Pela 1 and Pela 2. The study was carried out between November 2018 and January 2019.

\section{Study subjects}

The study subjects were females aged 60 years and over with the inclusion criteria of being capable of good communication and capable of active locomotion without walking aids. The exclusion criteria used were: suffering from heart disease, stroke, kidney disease, consumption of 25(OH)D supplements, or corticosteroids and hormone replacement therapy. The subjects were interviewed by 10 Health Center cadres using a questionnaire consisting of a number of items, including age. All participants signed informed consent.

The calculated optimal sample size was 27 subjects, but in this study 45 subjects were used. The sample size was determined from a type 1 error (alpha) of $5 \%$, for a one sided hypothesis so that $Z \alpha=1.64$. The type 2 error was set at $10 \%$, so that $Z \beta=1.28$ and the correlation $\mathrm{r}=0.6 .^{(17)}$ The study subjects were selected by cluster and simple random sampling.

\section{Measurement of carotid intima-media thickness}

Carotid-intima media thickness measurement was by means of carotid duplex USG, with the subject in the supine position and the neck slightly extended and rotated away from the side to be examined. The $10 \mathrm{MHz}$ linear transducer was placed on the neck and moved upwards from the supraclavicular region to the right and left mandibular angles. The measurement was performed on the distal part of the common carotid artery, i.e. on a $1-\mathrm{cm}$ long segment of the carotid bulb. On the screen a double-line would be visible, indicating the simultaneous capture of the near-wall and the far-wall. The CIMT measurements were done in duplicate at each visit, and the readings were reported to the nearest $0.1 \mathrm{~mm}$. The mean of the two measurements was used in the analysis. The instrument used was the Mindray Z6 Digital Ultrasonic Imaging system. The CIMT value used was that for the left carotid artery, since this is more closely correlated with the biochemical parameters, whereas the right carotid artery is more closely correlated with hemodynamic parameters. ${ }^{(18)}$

\section{Measurement of body mass index}

After ascertaining that the barefooted subject was standing upright and not slouching, height was measured by means of a portable microtoise with a precision of $0.1 \mathrm{~cm}$. Weight was measured using Sage portable scales and expressed in $\mathrm{kg}$ with a precision of $0.1 \mathrm{~kg}$. Body mass index (BMI) was calculated from the weight in $\mathrm{kg}$ divided by height in meters squared and categorized as follows: underweight $(<18.5$ $\left.\mathrm{kg} / \mathrm{m}^{2}\right)$, normal $\left(18.5-22.9 \mathrm{~kg} / \mathrm{m}^{2}\right)$, overweight $\left(23.0-27.5 \mathrm{~kg} / \mathrm{m}^{2}\right)$ and obesity $\left(>27 \mathrm{~kg} / \mathrm{m}^{2}\right)$. Blood pressure was measured with a Riester mercury sphygmomanometer and the results expressed in $\mathrm{mmHg}$. 


\section{Measurement of lipid profile}

Blood samples were collected from each subject to a volume of $10 \mathrm{ml}$ by means of venipuncture from the cubital vein, after a 12 14 hour overnight fast, then the blood samples were centrifuged at $3000 \mathrm{rpm}$ for 15 minutes. The serum was separated and placed in an automatic analyzer. The normal total cholesterol concentration was defined at $<200 \mathrm{mg} / \mathrm{dL}$, low density lipoprotein (LDL) cholesterol at $<100 \mathrm{mg}$ / $\mathrm{dL}$, high density lipoprotein (HDL) cholesterol $>40 \mathrm{mg} / \mathrm{dL}$, and triglycerides $<150 \mathrm{mg} / \mathrm{dL}$. Determination of total cholesterol concentration was performed by the cholesterol oxidase/ peroxidase aminophenazone method (CHODPAP reagent), with a coefficient of variation of 1.19. For HDL and LDL cholesterol the coefficients of correlation were 1.43 and 2 , respectively. Triglycerides were measured with the glucose dehydrogenase (GDH)-nicotinamide adenine dinucleotide (NAD) method, with a coefficient of correlation of 1.27. ${ }^{(19)}$

\section{Measurement of blood glucose}

This was done with the GODPAP method, with coefficient of variation of 1.05 . The normal value of fasting blood sugar was $<100 \mathrm{mg} / \mathrm{dL}$. ${ }^{(2)}$

\section{Measurement of 25(OH)D}

The examination used $200 \mu \mathrm{L}$ of the serum sample with the addition of $500 \mu \mathrm{L}$ acetonitrile containing vitamin as internal standard for the precipitation of the protein, homogenized by vortexing for 2 minutes, then centrifuged at $14.000 \mathrm{rpm}$ for 10 minutes. A volume of $100 \mu \mathrm{L}$ of the supernatant was transferred into an amber-colored HPLC vial and tightly capped. The standard was prepared as follows: Standard stock solution of vitamin D in methanol was serially diluted vitamin D3 and D2: $10-50 \mathrm{ng} / \mathrm{ml}$. The standard was diluted using the same procedure as for the serum sample by adding acetonitrile, then homogenized by vortexing for 2 minutes. The prepared sample was put into an HPLC vial and a volume of $2 \mu \mathrm{L}$ was injected into the LC-MS/MS system. The result of the analysis was read based on the molecular retention time from HPLC separation and the peak area as read from MS/MS. A value of $25(\mathrm{OH}) \mathrm{D}<10 \mathrm{ng} / \mathrm{mL}$ was designated deficiency, $10-<30 \mathrm{ng} / \mathrm{mL}$ insufficiency, $30-100 \mathrm{ng} / \mathrm{mL}$ sufficiency, $>100 \mathrm{ng} / \mathrm{mL}$ toxicity. ${ }^{(21)}$

\section{Data analysis}

Analysis of background characteristics and normality of data distribution was performed using the Kolmogorov-Smirnov test. Normal data distributions were presented as mean, standard deviation and percentage. Simple linear regression analysis was done to determine the correlation between CIMT and 25(OH)D concentration. Initially simple linear regression analysis was performed, then multiple linear regression analysis of the associations presenting $p$ values of $<0.20$ in the simple regression analysis was to be carried out. The statistical analysis was by means of the SPSS software for Windows, version 17 (SPSS, Chicago), and a $p$ value of $<0.05$ was declared statistically significant.

\section{Ethical clearance}

Ethical clearance in this study was issued by the Ethics Commission, Faculty of Medicine, Trisakti University under No. 140/KER/FK/1/ 2019.

\section{RESULTS}

Mean age of the subjects was $65.64 \pm 4.25$ years and mean BMI $24.98 \pm 3.93 \mathrm{~kg} / \mathrm{m}^{2}$. Mean total cholesterol was $203.22 \pm 30.77 \mathrm{mg} / \mathrm{dL}$, mean LDL cholesterol $144.20 \pm 34.12 \mathrm{mg} / \mathrm{dL}$, mean HDL cholesterol $53.44 \pm 12.49 \mathrm{mg} / \mathrm{dL}$ and mean triglycerides $123.28 \pm 48.07 \mathrm{mg} / \mathrm{dL}$. Mean $25(\mathrm{OH}) \mathrm{D}$ concentration was $11.71 \pm 3.93 \mathrm{ng} /$ $\mathrm{mL}$, categorized as vitamin $\mathrm{D}$ insufficiency, mean left CIMT was $0.61 \pm 0.10 \mathrm{~mm}$. There were 15 $(33.33 \%)$ elderly women with $25(\mathrm{OH}) \mathrm{D}$ deficiency (Table 1). 
Table 1. Characteristics present in all elderly women $(n=45)$

\begin{tabular}{lc}
\hline \multicolumn{1}{c}{ Characteristic } & $\begin{array}{c}\text { Mean } \pm \text { SD } \\
(\mathbf{n}=\mathbf{4 5})\end{array}$ \\
\hline Age (years) & $65.64 \pm 4.25$ \\
Body Mass Index $\left(\mathrm{kg} / \mathrm{m}^{2}\right)$ & $24.98 \pm 3.93$ \\
Total cholesterol $(\mathrm{mg} / \mathrm{dL})$ & $203.22 \pm 30.77$ \\
LDL cholesterol $(\mathrm{mg} / \mathrm{dL})$ & $144.20 \pm 34.12$ \\
HDL cholesterol $(\mathrm{mg} / \mathrm{d} \mathrm{L})$ & $53.44 \pm 12.49$ \\
Triglycerides $(\mathrm{mg} / \mathrm{dL})$ & $123.28 \pm 48.07$ \\
Fasting blood glucose $(\mathrm{mg} / \mathrm{dL})$ & $97.07 \pm 11.09$ \\
Systolic blood pressure $(\mathrm{mmHg})$ & $125.95 \pm 24.52$ \\
Diastolic blood pressure $(\mathrm{mmHg})$ & $77.60 \pm 12.56$ \\
25(OH)D concentration $(\mathrm{ng} / \mathrm{mL})$ & $11.71 \pm 3.93$ \\
25(OH)D deficiency $(\mathrm{n}, \%)$ & $15(33.33)$ \\
CIMT $(\mathrm{mm})$ & $0.61 \pm 0.10$ \\
\hline
\end{tabular}

$25(\mathrm{OH}) \mathrm{D}=$ plasma concentration of $25-\mathrm{OH}$-vitamin $\mathrm{D}$; CIMT: carotid intima-media thickness

Initially simple linear regression analysis was performed, in which the results showed that only the $25(\mathrm{OH}) \mathrm{D}$ concentration as the independent variable was significantly associated with CIMT ( $\beta=-0.01195 \%$ C.I. $=-0.020$ to -0.003$)$. It turned out that there was no other independent variable with $p<0.20$, so that the multiple linear regression could not be performed (Table 2).

\section{DISCUSSION}

In this study an inverse relationship was found between $25(\mathrm{OH}) \mathrm{D}$ concentration and CIMT. Similar results were obtained in the study of Hao et al. ${ }^{(22)}$ who found a negative relationship between 25(OH)D concentration and CIMT in Chinese post-menopausal women. A different team of investigators, Carreli et al., ${ }^{(3)}$ also found a negative relationship between $25(\mathrm{OH}) \mathrm{D}$ concentration and CIMT. Differing results were obtained in the study conducted by Monteiro Junior et al. ${ }^{(23)}$ who showed a significant inverse linear relationship between serum $25(\mathrm{OH}) \mathrm{D}$ concentration and CIMT. The inverse association between serum levels of $25(\mathrm{OH}) \mathrm{D}$ and CIMT, initially observed in Monteiro's study, became non-significant after the inclusion of the variable age in the multivariate analysis model. On the other hand, the study supported the role of traditional risk factors for atherosclerosis, with independent associations of the variables age, male gender, smoking, systolic blood pressure, fasting glucose and LDL cholesterol with CIMT.

The role of vitamin $\mathrm{D}$ in normal physiological conditions has cardioprotective effects by inhibiting cholesterol uptake and preventing the development of atherogenesis. Our study results showed that there were 15 (33.33\%) elderly women with vitamin D deficiency. Similar results were obtained in the study of Setiati et al. ${ }^{(13)}$ in Jakarta and Bekasi, who found 25(OH)D deficiency in $35.1 \%$ of women aged $60-75$ years. Consistent results were obtained in a French study involving 125 patients aged 75 years and older, where $43 \%$ had vitamin D deficiency. ${ }^{(24)}$ Other study results in both tropical and temperate zone countries showed a sufficiently high proportion of $25(\mathrm{OH}) \mathrm{D}$, ranging from 33.3 to $43 \%$. Lack of physical activity and sun exposure are most likely the key reasons behind this relevant vitamin $\mathrm{D}$ deficiency in elderly people. ${ }^{(25)}$

Vitamin D deficiency plays an important role in the development and progress of atherosclerosis. Low $25(\mathrm{OH})$ vitamin D concentrations influence the activities of lymphocytes and macrophages in causing chronic inflammation in the arterial wall. ${ }^{(26)} \mathrm{Al}$ Mheid et al. ${ }^{(27)}$ in their study on 554 healthy subjects found that low vitamin D concentrations

Table 2. Independent factors of CIMT identified by simple linear regression analysis $(n=45)$

\begin{tabular}{cccc}
\hline Independent variable & $\boldsymbol{\beta}$ & $\mathbf{9 5 . 0 \%}$ Confidence interval for $\boldsymbol{\beta}$ & $\mathbf{p ~ v a l u e}$ \\
\hline Age (years) & 0.001 & $-0.077-1.468$ & 0.076 \\
Total cholesterol & -0.002 & $-0.008-0.008$ & 0.586 \\
LDL cholesterol & 0.002 & $-0.005-0.010$ & 0.503 \\
HDL cholesterol & 0.002 & $-0.007-0.010$ & 0.719 \\
Triglycerides & 0.001 & $-0.001-0.002$ & 0.564 \\
BMI & 0.001 & $-0.008-0.009$ & 0.901 \\
25(OH)D & -0.011 & $-0.020--0.003$ & 0.009 \\
\hline
\end{tabular}


are associated with rigidity of blood vessels and endothelial function.

The study of Pilz et al. ${ }^{(28)}$ found that low serum $25(\mathrm{OH})$ vitamin $\mathrm{D}$ was an independent predictor of fatal stroke in $>3000$ subjects who were routinely examined by coronary angiography. Hypovitaminosis D is independently associated with myocardial infarction, stroke, peripheral vascular disease, and cardiovascular mortality. ${ }^{(27)}$ Other influences of vitamin D on lipids are decreases in LDL cholesterol and triglyceride levels. ${ }^{(29)}$

Deleskog et al. ${ }^{(12)}$ found that vitamin D does not play a role in combating subclinical atherosclerosis. This may be due to dietary differences, vitamin D supplementation, genetic factors, and habitual exposure to sunlight. ${ }^{(3)}$

The limitation of this study is that the crosssectional design of the study does not allow for the determination of an increasing or decreasing effect of vitamin D on CIMT. Moreover, the reproducibility of the CIMT measurements, performed by a single experienced examiner, was not tested.

The results of this study show that elderly women have low vitamin D concentrations, so that the patients can be informed and pay attention to their vitamin D level, especially the elderly, among others by increasing the intake of vitamin D-rich foods and by doing regular physical exercise, particularly for exposure to ultraviolet rays of the morning sun, in order to delay thickening of the carotid artery tunica intima and media.

It is hoped that experimental studies may be conducted to determine the effect of vitamin D administration to elderly women. In addition, into this future study should be entered a larger number of risk factors that are associated with vitamin D, such as obesity and diabetes mellitus, so as to obtain more complete results.

\section{CONCLUSIONS}

There is a significant inverse relationship between 25(OH) vitamin D and CIMT in elderly women. These findings in older women suggest a potential role for vitamin $\mathrm{D}$ in the development of subclinical atherosclerosis.

\section{CONFLICT OF INTEREST}

None declared.

\section{ACKNOWLEDGMENTS}

The investigators express their utmost gratitude to the Dean and Vice-Deans of the Faculty of Medicine, Trisakti University, for their moral and material support of this study. We also thank the Head of Mampang Health Center and staff and all participants of this study.

\section{REFERENCES}

1. Zhong W, Cruickshanks KJ, Schuberg CR, et al. Carotid atherosclerosis and 10-year changes in cognitive function. Atherosclerosis 2012;224:50610. doi: 10.1016/j.atherosclerosis.2012.07.024.

2. Singh AS, Atam V, Patel ML, et al. Carotid intima media thickness as areflextion of generalized atherosclerosis is related to body mass index in ischemic stroke patients. Am J Med Sci 2013;5:22834. doi: 10.4103/1947-2714.109200.

3. Carrelli AL, Walker MD, Lowe H, et al. Vitamin D deficiency is associated with subclinical carotid atherosclerosis. Stroke 2011;42:2240-45. doi: 10 1161/STROKEAHA 110608539.

4. Park KH, Park WJ. Endothelial dysfunction: clinical implications in cardiovascular disease and therapeutic approaches. J Korean Med Sci 2015; 30:1213-25.

5. Pusparini. Defisiensi vitamin D terhadap penyakit. Indonesian J Clin Pathol Med Lab 2014;21:90-5.

6. Molinary C, Uberti F, Grossini F, et al. 25Dihydroxy cholecalciferol induces nitric oxide production in cultured endothelial cells. Cell Physiol Biochem 2011;27:661-8.

7. Polidoro I, Properzi G, Marampon F, et al. Vitamin D protecs human endothelial cells from $\mathrm{H} 2 \mathrm{O} 2$ oxidant injuri through the Mek/Erk Sirtl axis activations. J Cardiovasc Transl Res 2013;6:22131.

8. Mandarino NR, Monteiro Junior FC, Salgado JVL, et al. Is vitamin D deficiency a new risk for cardiovascular disease? Open Cardiovasc Med J 2015;9:40-9. doi: 10.2174/187419201509010040.

9. Kaufman JM. Benefits of vitamin D supplementation. J Am Phy Surg 2009;14:38-45. 
10. Byrnes KR, Ross CB. The current role of carotid duplex ultrasonography in the management of carotid atherosclerosis: foundations and advances. Int J Vasc Med 2012;2012. DOI: http:/ /dx.doi.org/10.1155/2012/187872.

11. Kassi E, Adamopoulus C, Basdra EK. Role of vitamin D in atherosclerosis. Circulation 2013;128: 2617-31. doi: 101161/CIRCULATIONAHA 113002654 .

12. Oemardi M, Horowitz M, Wishart JM, et al. The effect of menopause on bone mineral density and bone related biochemical variables in Indonesian women. Clin Endocrinol 2007;67:93-100.

13. Setiati S. Pengaruh sinar ultraviolet B matahari terhadap konsentrasi vitamin $\mathrm{D}$ dan hormon paratiroid pada perempuan usia lanjut Indonesia. J Kes Masy Nas 2008;2:147-53.

14. Arifin Z, Hestiantoro A, Baziad A. Pemberian susu yang difortifikasi kalsium kadar tinggi dan vitamin D memperbaiki turnover tulang perempuan pascamenopause. Maj Obstet Ginekol Indones 2010;34:31-8.

15. Reis JP, von Muhlen D, Michos ED, et al. Serum vitamin $\mathrm{D}$, parathyroid hormone levels, and carotid atherosclerosis. Atherosclerosis 2009;207:585-90.

16. Deleskog A, Piksasova O, Silviera A, et al. Serum 25-hydroxy vitamin D concentration in subclinical carotid atherosclerosis. Arterioscler Thromb Vasc Biol 2013;33:2633-8.

17. Abd El-hadi EA, El-sherbeny AA, Baha El-din AM, et al. Study of possible relation between vitamin-D status and subclinical atherosclerosis. Adv Res Biol Sci 2015;2:73-81.

18. Luo X, Yang Y, Cao T, et al. Differences in left and right carotid intima-media thickness and the associated risk factors. Clin Radiol 2011;66:393-8. doi: 10.1016/j.crad.201012.002.

19. Arsana PM, Rosanda R, Manaf A, et al. Panduan pengelolaan dislipidemia di Indonesia. Jakarta: PB PERKENI 2015.

20. Soelidtijo SA, Novido H, Rudijanto A, et al. Konsensus pengelolaan dan pencegahan diabetes melitus tipe 2 di Indonesia. Jakarta: PB.PERKENI; 2015.
21. Bianchi S, Maffei S, Prontera C, et al. Preanalytical, analytical (Diasorin Liaison) and clinical variables potentially affecting the $25 \mathrm{OH}$ vitamin D estimation. Clin Biochem 2012;45:16527.

22. Hao Y, Ma X, Luo Y, et al. Inverse association of serum vitamin $\mathrm{D}$ in relation to intima-media thickness in Chinese postmenopausal women. PLoS ONE 2015;10:1-10. doi: 10.1371/Journal. pone.0122803.

23. Monteiro Junior FC, Mandarino NR, Santos EM, et al. Correlation between serum 25 hydroxyvitamin D levels and carotid intima media thickness in a Brazilian population descended from African slaves. Braz J Med Biol Res 2018;5:2-8. doi: 10 1590/1414-431X20177185.

24. Kweder H, Eidi H. Vitamin D deficiency in elderly: Risk factors and drugs impact on vitamin D status. Avicenna J Med 2018;8:139-46. doi: 10.4103/ajm.AJM_20_18.

25. Wyskida M, Wieczorowska-Tobis K, Chudek J. Prevalence and factors promoting the occurrence of vitamin D deficiency in the elderly. Postepy Hig Med Dosw 2017;71:198-204.

26. Wang L, Song Y, Manson JE, et al. Circulating 25-hydroxy-vitamin D and risk of cardiovascular disease: a meta-analysis of prospective studies. Circ Cardiovasc Qual Outcomes 2012;5:819-29. doi: 10.1161/Circoutcomes112967604.

27. Al Mheid F, Patel R, Murrow J. Vitamin D status is associated with arterial stiffness and vascular dysfunction in healthy humans. J Am Coll Cardiol 2011;58:186-92. doi: 10.1016/j.jacc.2011.02.051.

28. Pilz S, Dobing H, Fischer JE. Low vitamin D levels predict stroke in patient referred to coronary angiography. Stroke 2008;39:2611-13. doi: 10. 1161/STROKEAHA 107513655.

29. Lupoli R, Vaccaro A, Ambrosino P, et al. Impact of vitamin $\mathrm{D}$ deficiency on subclinical carotid atherosclerosis: a pooled analysis of cohort study. J Clin Endocrinol Metab 2017;102:214653. 